for the full-time continuation of academic research, awards will normally be made to those who have obtained the doctorate within the preceding year, or are expected to receive that degree not later than the beginning of the next fellowship term which starts on July 1 each year. The committee of award will consist of seven members of the scientific staff of Bell Telephone Laboratories who are actively and creatively engaged in research in the respective fields of physics, mathematics and chemistry. In making the selection for awards, the primary criteria will be demonstrated research ability of the applicant, the fundamental importance of the problem he proposes to attack, and the likelihood of his development as a scientific man. Selection for a fellowship award and its acceptance will involve no implication or commitment on the part of Bell Telephone Laboratories or on the part of the recipient as to later employment in the Laboratories.

\section{National Physical Laboratory: Appointments}

THE Secretary of the Department of Scientific and Industrial Research has announced the following appointments at the National Physical Laboratory: Mr. W. F. Higgins, secretary of the National Physical Laboratory, has been appointed superintendent of the Physics Division of the Laboratory, following a considerable period in which he had been acting in that capacity after the death of the late Dr. G. W. C. Kaye; Dr. G. A. Hankins, of the National Physical Laboratory, has been promoted superintendent of the Engineering Division of the Laboratory to fill the vacancy caused by the resignation of Dr. S. L. Smith ; Mr. E. S. Hiscocks, of the Raw Materials Department, Ministry of Supply, and previously of the Department of the Government Chemist, has been appointed secretary of the National Physical Laboratory in succession to Mr. W. F. Higgins.

\section{London School of Economics : Appointments}

THE following appointments have been made in the University of London : Dr. R. W. Firth has been appointed as from October 1 to the University chair of anthropology tenable at the London School of Economics. Since $194 \mathrm{I}$ he has been in Government employment at the Admiralty, and in July 1944 he was appointed secretary to the Colonial Social Science Research Council. Dr. R. G. D. Allen has been appointed as from October 1 to the University chair of statistics tenable at the School. Since 1940 he has been in the United States on government service, and is at present British director of statistics to the Combined Production and Resources Board at Washington.

\section{The Night Sky in December}

FuLI moon occurs on Nov. 30d. 00h. 52m. U.T. and also on Dec. $29 \mathrm{~d}$. 14h. $38 \mathrm{~m}$.; new moon occurs on Dec. $15 \mathrm{~d}$. $14 \mathrm{~h} .34 \mathrm{~m}$. The following conjunctions with the moon take place: Dec. 2d. 08h., Saturn $0 \cdot 1^{\circ}$ N. ; Dec. 8 d. $09 \mathrm{~h} .$, Jupiter $4^{\circ} \mathrm{S}$.; Dec. $16 \mathrm{~d}$. 17h., Mercury $1^{\circ} \mathrm{S} . ;$ Dec. 19d. 00h., Venus $0.2^{\circ} \mathrm{S}$. ; Dec. 29 d. $14 \mathrm{~h}$., Saturn $0 \cdot 3^{\circ} \mathrm{N}$. In addition to these occultations, Mercury is in conjunction with Mars, Mercury $3 \cdot 6^{\circ}$ N., on Dec. 29 d. $05 \mathrm{~h}$. The following occultations of stars brighter than magnitude 6 take place: Dec. 3d. 2h. $53 \cdot 9 \mathrm{~m}$, 63 Gemi. $(R)$; Dec. 27d. 17h. $40 \cdot 2 \mathrm{~m}$., $i$ Taur. $(D)$. The times refer to the latitude of Greenwich and $D$ and $R$ refer to disappearance and reappearance, respectively. Mercury sets about an hour after the sun at the beginning and middle of the month and is in inferior conjunction on December 23 . Venus sets at $18 \mathrm{~h} .20 \mathrm{~m}$., $18 \mathrm{~h}$. $58 \mathrm{~m}$., and $19 \mathrm{~h} .46 \mathrm{~m}$. at the beginning, middle and end of the month respectively. Mars is too close to the sun for favourable observation, rising $16 \mathrm{~m}$. before the sun on December 1 and $46 \mathrm{~m}$. before the sun on December 31 . Jupiter rises at midnight in the middle of the month and is a conspicuous object during the morning hours. Saturn rises at $17 \mathrm{~h} .57 \mathrm{~m} ., 16 \mathrm{~h} .53 \mathrm{~m}$., and $15 \mathrm{~h} .43 \mathrm{~m}$. at the beginning, middle and end of the month respectively and can be seen south of $\varepsilon$ Geminorum. Winter solstice is on Dec. 21d. 23h. The Geminid meteors are active in the early part of the month.

\section{Announcements}

We regret to announce the death of Sir Arthur Eddington, O.M., F.R.S., Plumian professor of astronomy and experimental philosophy in the University of Cambridge, on November 21, aged sixty-one.

Dr. F. W. Lanchester, the inventor and pioneer in the development of the motor-car and the aeroplane, has been awarded the 1945 James Watt International Medal. The medal is awarded by the Council of the Institution of Mechanical Engineers, with the collaboration of the major engineering institutions of the world. He is only the fourth recipient of the James Watt Medal ; the others were Henry Ford, Orville Wright and M. Michel.

Dr. J. A. Fleming, general secretary of the American Geophysical Union of the U.S. National Research Council, announces that Mr. Waldo E. Smith has been appointed to the newly created post of executive secretary of the Union. Mr. Smith has recently been engaged on hydraulic engineering and hydrological studies with the Public Roads Administration, Washington, D.C.

Six popular lectures on astronomy will be given on Fridays at 6.30 , beginning on December 1, at the rooms of the Royal Astronomical Society in Burling. ton House, Piccadilly, London, W.1. The lectures are for members of the British and Allied Forces and admission is by ticket only, obtainable from Service organizations or from the Assistant Secretary, Royal Astronomical Society.

ThE Conference on the "Nutritional Role of the Micro-flora in the Alimentary Tract", arranged by the Nutrition Society (English Group), which was to have been held last July and had to be postponed, will, it is now announced, take place on December 30, beginning at 11 a.m. Further details can be obtained from the Honorary Secretary, Dr. Leslie J. Harris, Nutritional Laboratory, Milton Road, Cambridge.

The Conference of the Association of Special Libraries and Information Bureaux which had to be postponed in September will now be held on Decermber 9 and 10 at the rooms of the Royal Society, London, W.1. The opening address will be given by the president, Sir Frederic Kenyon, on "Organised Knowledge in the World of the Future". There will be a symposium on "The Empire Contribution to the Flow of World Information" and a discussion on the status and education of special librarians and information officers, together with several shorter papers. Particulars can be obtained from the ASLIB Office, 31 Museum Street, London, W.C.1. 